\title{
INNOVATIVE APPROACHES AND THEIR APPLICATION IN MEASURING BUSINESS PERFORMANCE
}

\author{
Jarmila Horváthová, ${ }^{1}$ Martina Mokrišová ${ }^{2}$
}

\begin{abstract}
In the area of business performance evaluation, we should pay attention to innovative approaches to performance measurement. They include the application of a matrix model. This concept was initially used for addressing the efficiency of input and output transformations. However, the terms 'efficiency' and 'performance' are closely linked. Some authors even assign them the same meaning. Based on the above-mentioned, a linear programming model for addressing the problems of input and output transformations can also be applied for business performance measurement. The benefit of this paper is the measurement of business performance applying a matrix model. One of the significant outcomes of such matrix model is the formation of new indicators, which can be beneficial in business performance measurement. Another positive aspect of this approach is the creation of a network of indicators assessing business efficiency, effectiveness and performance. There are strong links between indicators in a network, which can be mathematically described. Based on the knowledge, the management of a business can focus on those functional areas, which are preconditioned for business performance and efficiency improvement.
\end{abstract}

JEL Classification Numbers: C02, D59, D89; DOI: http://dx.doi.org/10.12955/cbup.v5.921

Keywords: business, efficiency, indicator, input, matrix, model, output, performance

\section{Introduction}

The measurement of business performance is nowadays a very actual problem. Recently there is a decrease in use of conventional profitability indicators as synthetic measures of business performance. Nowadays, due to the changes in the economic environment, new tendencies arise. These tendencies originate in the areas with the most developed capital markets and are linked to the shift of top indicators of performance measurement towards maximization of shareholder value. The result of this is the use of so-called value criteria for business performance measurement.

\section{Literature review}

Conventional financial indicators have a low predictive value in looking for ways to improve business performance, especially in the long-term. This is due to the fact that these indicators measure and evaluate special area of business financial health. "It is important to supplement conventional financial indicators with other more dynamic and more prospective indicators, which are adjusted to specific competitive conditions" (Gallo, 2013). The aim in performance measurement is to monitor and compare the implementation of performance results with the planned level of performance, to monitor strategy implementation, to identify accompanying fundamental problems and to perform measures to eliminate deviations (Dudoková, 2004).

From this point of view, it is necessary to implement modern indicators of performance measurement which are based on market principles, not on accounting, and proceed from the theory of value management and the acceptance of the internal and external risks and are applicable in business valuation (Mařík, Maříková, 2005; Suhányiová, Suhányi, 2011). "Therefore, basic financial fields of evaluation and measurement of business performance can be supplemented by more recent and modern indicators and methods" (Kislingerová et al., 2011). "Evaluation using modern methods with the application of market characteristics such as the EVA indicator (the EVA model has been known since 1980. Its authors are representatives of Stewart \& Co., Americans Joel M. Stern and G. Bennett Stewart III.), INEVA, MVA, RONA, WACC or indicators based on FCF, CVA and others" (Stern, 2015).

In addition to measuring performance with the use of financial indicators, we focus on business performance measurement applying a set of non-financial indicators which are based on experiments from the early 80s, when Peters and Waterman (1982) proposed eight factors that lead to business success and Rockart (1981) and Chung (1987) suggested critical success factors. As the comprehensive approach to business performance measurement, the concept of a Balanced Scorecard (Kaplan, Norton, 2000) developed in the 1990s followed. Another business performance evaluation method which uses non-financial indicators is the method of Harry Pollak (2004). "Methods of

\footnotetext{
${ }^{1}$ Faculty of Management, University of Prešov in Prešov, jarmila.horvathova@unipo.sk

${ }^{2}$ Faculty of Management, University of Prešov in Prešov, martina.mokrisova@unipo.sk
} 
performance evaluation based on non-financial indicators also include techniques of determining measures for business management - for example CMM (Capability Maturity Matrices), performance pyramid, EP ${ }^{2} \mathrm{M}$ (Effective Progress and Performance Measurement) and the management of performance processes" (Sink and Tuttle, 1989). "Modern techniques of performance management and measurement also include Total Quality Management, Six Sigma, Benchmarking, Kaizen, Business Processes Reengineering and others" (Horváthová et al., 2014). These approaches represent a multicriteria evaluation of performance with the use of financial and non-financial performance indicators applicable in all areas of value added (Suhányi, Suhányiová, 2014).

An important benefit in the issue of performance measurement is the application of a matrix model processed in the contributions of Grell, Hyránek (2012, 2014). According to these authors conventional indicators are a very good basis for further examination of performance applying mathematical methods. They also criticize one-way orientation of performance measurement on output measures and point out the necessity of incorporating intensity indicators to performance measurement models. Based on above-mentioned, business performance can be examined by a matrix model, in which various combinations of inputs and outputs are applied. One of the important results of the matrix model is the definition of new indicators, which may be beneficial for business performance measurement and evaluation. In addition to the mentioned authors, efficiency of production systems with the use of a matrix model is also addressed by Cibulka (2007a); Cibulka (2007b); Klieštik (2009), Huai et al. (2011). The positive aspect of this approach is that indicators measuring business efficiency, effectiveness and performance create a network with strong relations between them (Štefko, Gallo, 2015), which results in the synergic effect of indicators'impact on business performance.

\section{Data and methodology}

The research problem of this paper was focused on the analysis of business performance. The EVA indicator and linear programming aimed at addressing the problem of input and output transformations were used to calculate business performance.

The formulation of the research problem: Is the EVA indicator a synthetic indicator of business performance measurement, the value of which reflects the impact of functional areas of business? Is business efficiency precondition for its performance? Is the matrix model suitable input for performance measurement? Is performance measurement based on the matrix model an adequate alternative to measuring performance by EVA?

The research objective was to calculate and analyze business performance with the use of the EVA indicator and the matrix model addressed as a linear programming model applying the simplex method.

In accordance with the research objective, we proposed the hypothesis:

$\mathrm{H}$ : We suppose that the results of the performance measured by the EVA indicator are identical with the results of efficiency measured with the use of model of input and output transformations.

The research was realized on a sample of 30 businesses operating in the Slovak heat industry. For this research sample, we processed a matrix model, which was an input for efficiency and performance analysis.

For the creation of the matrix model, which we used for the evaluation of efficiency and performance of businesses operating in Slovak heat industry, we selected these data: as inputs, we chose A Assets, FA - Fixed Assets, MC - Material costs, E - Equity, C - Costs; as outputs, we chose R Revenues, S - Sales, VA - Value added, EBIT - Earnings before interest and taxes and EAT Earnings after taxes. With the use of mentioned inputs and outputs we created a matrix of input and of output transformations, which consists of a number of important indicators of business performance -

Quadrant A in above-mentioned matrix model is formed by indicators of efficiency and effectiveness. Quadrant B consists of indicators of assets and capital structure. Quadrant C is formed by indicators designed as input/output. This group includes indicators of intensity. Quadrant D consists of indicators of output/output. This quadrant includes indicators of structure, but also indicators of output profitability. From the structure of this matrix, it is obvious, that performance was evaluated by a group of indicators from all areas determining it. The matrix consists of indicators of efficiency, 
effectiveness, and intensity and in terms of financial indicators, there are indicators of profitability, activity, and capital structure.

\begin{tabular}{|c|c|c|c|c|c|c|c|c|c|c|}
\hline & $\overline{\mathbf{R}}$ & $\bar{S}$ & $\overline{\text { VA }}$ & $\overline{\text { EBIT }}$ & $\overline{\text { EAT }}$ & $\overline{\mathrm{A}}$ & FA & MC & $\overline{\mathbf{E}}$ & $\overline{\mathrm{C}}$ \\
\hline $\mathbf{A}$ & 0.72 & 0.65 & 0.17 & 0.04 & 0.03 & 1 & 0.77 & 0.40 & 0.44 & 0.68 \\
\hline FA & 0.93 & 0.84 & 0.23 & 0.06 & 0.03 & 1.30 & 1 & 0.52 & 0.57 & 0.89 \\
\hline MC & 1.80 & 1.62 & 0.44 & 0.11 & 0.06 & 2.51 & 1.93 & 1 & 1.11 & 1.72 \\
\hline $\mathbf{E}$ & 1.62 & 1.46 & 0.39 & 0.10 & 0.06 & 2.26 & 1.75 & 0.90 & 1 & 1.55 \\
\hline $\mathbf{C}$ & 1.05 & 0.95 & 0.25 & 0.06 & 0.04 & 1.46 & 1.13 & 0.58 & 0.65 & 1 \\
\hline $\mathbf{R}$ & 1 & 0.90 & 0.24 & 0.06 & 0.04 & 1.39 & 1.08 & 0.56 & 0.62 & 0.95 \\
\hline $\mathbf{S}$ & 1.11 & 1 & 0.27 & 0.07 & 0.04 & 1.55 & 1.19 & 0.62 & 0.68 & 1.55 \\
\hline $\begin{array}{l}\text { VA } \\
\end{array}$ & 4.12 & 3.72 & 1 & 0.25 & 0.15 & 5.75 & 4.43 & 2.29 & 2.54 & 3.93 \\
\hline EBIT & 16.47 & 14.86 & 3.99 & 1 & 0.58 & 22.96 & 17.71 & 9.16 & 10.15 & 15.71 \\
\hline EAT & 28.37 & 25.58 & 6.88 & 1.72 & 1 & 39.53 & 30.50 & 15.77 & 17.48 & 27.06 \\
\hline \multicolumn{11}{|c|}{ Explanatory notes: } \\
\hline
\end{tabular}

\section{Results and discussion}

To evaluate the performance of businesses, we calculated the average value of the indicators EVA Equity and EVA Entity. From the 30 analyzed businesses, 14 businesses showed a positive value of the EVA indicator and 16 businesses had a negative value of this indicator. Based on these results we can say that the analyzed sample of businesses has difficulties in achieving optimum values of performance. Further analyses show that these problems are due to low liquidity and low profitability of the analyzed sample of businesses. Average values of EVA indicator are shown in Figure 1.

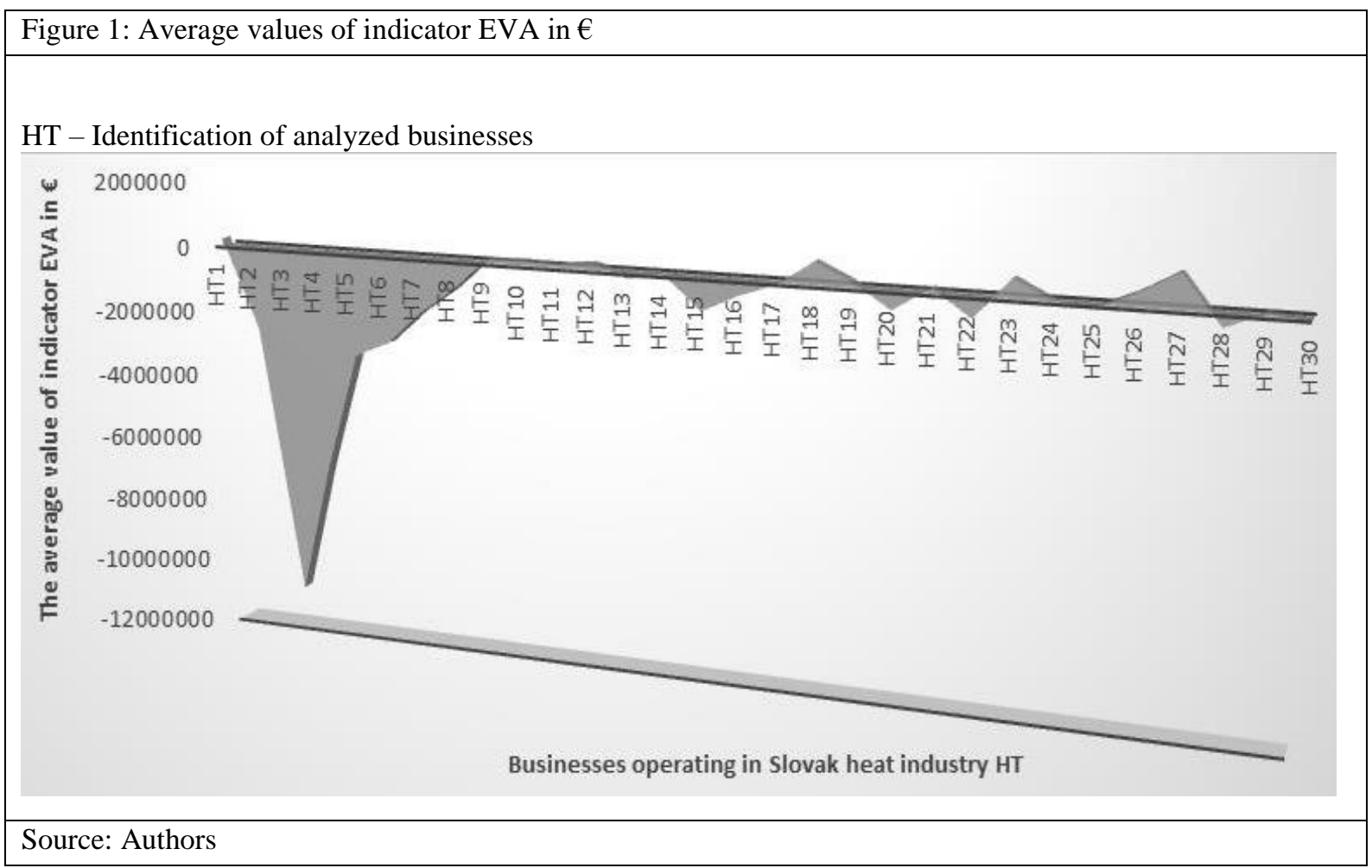

For the comparison of performance calculated by EVA indicator, we formulated a problem of linear programming (Table 2). The linear programming model consisted of 8 selected indicators - 4 indicators of intensity and 4 indicators of effectiveness. 


\begin{tabular}{|c|c|c|c|c|c|c|c|c|c|c|c|c|}
\hline & $\mathbf{u}_{1}$ & $\mathbf{u}_{2}$ & $\mathbf{u}_{3}$ & $\mathbf{u}_{4}$ & $\mathbf{t}_{1}$ & $\mathbf{t}_{2}$ & $\mathbf{t}_{3}$ & $\mathbf{t}_{4}$ & $\mathbf{W}_{1}$ & W2 & $\ldots .$. & \\
\hline \multirow[b]{3}{*}{1} & $\mathbf{x} 1$ & $\mathbf{x} 2$ & $\mathbf{X} 3$ & $\mathbf{x} 4$ & $\mathbf{X} 5$ & X6 & $\mathbf{X} 7$ & $\mathbf{X 8}$ & $\mathbf{X 9}$ & $\mathbf{X} 10$ & $\ldots .$. & \\
\hline & 1 & 2 & 3 & 4 & 5 & 6 & 7 & 8 & 9 & 10 & $\ldots .$. & \\
\hline & 0.975 & 0.484 & 0.219 & 0.696 & 0.039 & 0.107 & 0.104 & 2.067 & \multicolumn{2}{|l|}{-1} & & $=0$ \\
\hline 2 & 0.997 & 0.912 & 0.445 & 0.259 & -0.002 & - & 0.011 & 1.097 & \multicolumn{3}{|c|}{-1} & $=0$ \\
\hline \multirow{2}{*}{$\begin{array}{l}3 \\
4\end{array}$} & 0.998 & 1.863 & 1.436 & 0.549 & 0.000 & 0.000 & 0.013 & 0.537 & & & $\ldots \ldots$ & $=0$ \\
\hline & 0.990 & 2.197 & 1.957 & 0.550 & 0.003 & 0.002 & 0.014 & 0.455 & & & & $=0$ \\
\hline \multirow[t]{2}{*}{5} & 0.928 & 1.820 & 1.569 & 0.435 & 0.057 & 0.053 & 0.041 & 0.549 & & & & $=0$ \\
\hline & $\vdots$ & $\vdots$ & $\vdots$ & $\vdots$ & $\vdots$ & $\vdots$ & $\vdots$ & $\vdots$ & & & & $\vdots$ \\
\hline \multirow{5}{*}{$\begin{array}{l}29 \\
30\end{array}$} & 0.931 & 0.982 & 0.795 & 0.649 & 0.055 & 0.344 & 0.081 & 1.018 & & & & $=0$ \\
\hline & 0.965 & 2.173 & 2.007 & 0.540 & 0.030 & 0.076 & 0.023 & 0.460 & & & & $=0$ \\
\hline & & & & & 1 & 1 & 1 & 1 & & & & $=1$ \\
\hline & $\mathrm{u}_{1}$ & $\mathrm{u}_{2}$ & $\mathrm{u}_{3}$ & $\mathrm{u}_{4}$ & $\mathrm{t}_{1}$ & $t_{2}$ & $t_{3}$ & $\mathrm{t}_{4}$ & $\mathrm{w}_{1}$ & $\mathrm{w}_{2}$ & $\ldots .$. & $\geq 0$ \\
\hline & & & & & & & & Min & $\mathrm{w}_{1}+$ & $\mathrm{w}_{2}+$ & $\cdots \cdots$ & $=\mathrm{Z}$ \\
\hline \multicolumn{13}{|c|}{ Explanatory notes: } \\
\hline $\mathrm{x}_{1}$ & \multicolumn{2}{|c|}{ - Cost ratio } & & \multicolumn{3}{|c|}{$\mathrm{x}_{3}$ - Capital intensity } & & & \\
\hline $\mathrm{X}_{4}$ & \multicolumn{2}{|c|}{ - Material intensity } & \multicolumn{4}{|c|}{$\mathrm{X}_{5}-$ Return on Sales } & \multicolumn{3}{|c|}{$\mathrm{x}_{6}-$ Return on Equity } & & & \\
\hline $\mathrm{x}_{7}$ & \multicolumn{2}{|c|}{ - Return on Assets } & \multicolumn{4}{|c|}{$\mathrm{X}_{8}-$ Fixed assets turnover } & \multicolumn{3}{|c|}{$\mathrm{w}_{\mathrm{i}}$ - Deviations } & & & \\
\hline
\end{tabular}

The result of addressing the problem of linear programming is shown in Table 3 , while $u_{i}$ and $t_{r}$ are weights of selected indicators and $w_{j}$ are deviations. In the linear programming model, we minimized the sum of deviations. The results show that the highest weight in the model have the indicators Cost ratio, Return on sales, and Fixed assets turnover. From this point of view, we can consider these three indicators as the most important determinants of business efficiency and performance, whereas indicator Return on sales has a weight of 0,954 .

\begin{tabular}{|l|rrr|}
\hline \multicolumn{3}{|c|}{ Table 3: Output of linear programming model } \\
\hline \multicolumn{3}{|c|}{ Vectors $\boldsymbol{u}_{\boldsymbol{i}}, \boldsymbol{t}_{\boldsymbol{r}}$} & Deviations $\boldsymbol{w}_{\boldsymbol{j}}$ \\
\hline$u_{1}=0.291$ & $w_{1}=0.151$ & $w_{11}=0.17$ & $w_{21}=0.068$ \\
$u_{2}=0$ & $w_{2}=0.241$ & $w_{12}=0.02$ & $w_{22}=0.203$ \\
$u_{3}=0$ & $w_{3}=0.266$ & $w_{13}=0.186$ & $w_{23}=0.108$ \\
$u_{4}=0$ & $w_{4}=0.264$ & $w_{14}=0$ & $w_{24}=0.24$ \\
$t_{1}=0.954$ & $w_{5}=0.19$ & $w_{15}=0.146$ & $w_{25}=0.23$ \\
$t_{2}=0$ & $w_{6}=0.24$ & $w_{16}=0.213$ & $w_{26}=0.126$ \\
$t_{3}=0$ & $w_{7}=0.26$ & $w_{17}=0.215$ & $w_{27}=0.044$ \\
$t_{4}=0.046$ & $w_{8}=0.276$ & $w_{18}=0$ & $w_{28}=0.184$ \\
& $w_{9}=0.13$ & $w_{19}=0.184$ & $w_{29}=0.171$ \\
& $w_{10}=0.19$ & $w_{20}=0.154$ & $w_{30}=0.231$
\end{tabular}

Source: Authors

With the use of calculated vectors, we can quantify the efficiency of individual businesses operating in the Slovak heat industry and create an efficiency order (Table 4) with the use of formula $E_{j}=$ $\sum_{r} t_{r} c_{r j} / \sum_{i} u_{i} S_{M, i j}^{J}$, where $c_{r j}$ is a matrix of indicators of efficiency and $S_{M, i j}^{J}$ is a matrix of indicators of intensity.

Based on the results of the problem of linear programming we can say, that from the 30 analyzed businesses only 2 businesses reached a maximum value of efficiency at the level of 1 therefore, their performance is high. An efficiency less than 0.1 was achieved by 4 analyzed businesses. 


\begin{tabular}{|c|c|c|c|c|c|}
\hline $\begin{array}{c}\text { Efficiency } \\
\text { ranking }\end{array}$ & Efficiency & Business & $\begin{array}{c}\text { Efficiency } \\
\text { ranking }\end{array}$ & Efficiency & Business \\
\hline 1 & 1 & HT14 & 15 & 0.314 & HT28 \\
\hline 1 & 1 & HT18 & 16 & 0.305 & HT10 \\
\hline 2 & 0.927 & HT12 & 17 & 0.297 & HT5 \\
\hline 3 & 0.834 & HT27 & 18 & 0.267 & HT22 \\
\hline 4 & 0.748 & HT21 & 19 & 0.236 & HT16 \\
\hline 5 & 0.564 & HT23 & 20 & 0.219 & HT17 \\
\hline 6 & 0.511 & HT26 & 21 & 0.198 & HT25 \\
\hline 7 & 0.496 & HT9 & 22 & 0.179 & HT30 \\
\hline 8 & 0.468 & HT1 & 23 & 0.170 & HT2 \\
\hline 9 & 0.438 & HT15 & 24 & 0.143 & HT24 \\
\hline 10 & 0.410 & HT20 & 25 & 0.141 & HT6 \\
\hline 11 & 0.369 & HT29 & 26 & 0.094 & HT8 \\
\hline 12 & 0.357 & HT11 & 27 & 0.087 & HT7 \\
\hline 13 & 0.339 & HT13 & 28 & 0.085 & HT3 \\
\hline 14 & 0.338 & HT19 & 29 & 0.083 & HT4 \\
\hline
\end{tabular}

Based on the detailed analyses and calculations, we found out that businesses which achieve low efficiency, also reach a negative value of the EVA indicator, so their performance is low. We also found out that from the border efficiency of 0.3 downwards, the performance of businesses is low and from the value 1 to the border efficiency of 0.5 , the performance of businesses is high. In the efficiency range from 0.3 to 0.5 , there is a gray area where we cannot definitely say whether performance of businesses is low or high. In this range, businesses achieved positive or negative values of the EVA indicator. Business HT27, which achieved the highest value of the EVA indicator at the level of 1 million, had an efficiency of 0.83 . We can also mention business HT18, which reached the second place in the value of the EVA indicator as well as in the efficiency calculation.

\section{Conclusion}

Based on the research, we can conclude that business performance can be exactly measured by efficiency indicators. These measures are appropriate because they connect inputs and outputs. We proved that the results of performance measured by the EVA indicator are identical with the results of efficiency measured with the use of the model of input and output transformations. The hypothesis was confirmed. Based on the above-mentioned we can conclude that the EVA indicator is a synthetic indicator of business performance measurement. A synthetic measure is also the calculation of business performance applying the linear programming model because with its use we obtained one aggregate number which expresses business performance and takes into account all indicators of business performance evaluation.

\section{Acknowledgement}

This paper was prepared within the grant scheme VEGA no. 1/0887/17 - Increasing the competitiveness of Slovakia within the EU by improving efficiency and performance of production systems and grant scheme KEGA no. 058PU-4/2015 - Development of the cooperation of the Faculty of Management of the University of Prešov in Prešov with employers, enhancement of the professional experience of students and increasing the chances of the graduate students in the labor market.

\section{References}

Chung, K. H. (1987). Management: Critical success factors. Newton, MA: Allyn and Bacon, Inc.

Cibulka, V. (2007a). Prístup k hodnoteniu a postupy hodnotenia efektívnosti logistického systému podniku. Materials Science and Technology, 7(2). Retrieved from https://www.mtf.stuba.sk/docs//internetovy_casopis/2007/2/cibulka.pdf

Cibulka, V. (2007b). Aktívne manažovanie zefektívňovania procesov logistických ret’azcov logistického systému. Materials Science and Technology, 7(3). Retrieved from http://www.mtf.stuba.sk/docs/internetovy_casopis/ 2007/3/cibulka.pdf 
Dudoková, M. (2004). Meranie výkonnosti ako predpoklad úspešnej stratégie. Retrieved September, 8, 2014, from http://www.scss.sk/eommlspj/_data/VEGA\%202002-2004/RIESITELIA/DUDOKOVA\%20MALVINA/4zilina2004\%20 AFD.pdf

Gallo, P. (2013). Management and controlling analyses. Prešov: Dominanta.

Grell, M., \& Hyránek, E. (2012). Maticové modely na meranie výkonnosti produkčných systémov. Ekonomika a management, 5(1), 73-88. from: http://www.ekonomie-management.cz/download/1379590470_6eb0/2012_01+Ma ticove+modely+na+meranie+vykonnosti+produkcnych+systemov.pdf

Horváthová, J., Ižaríková, G., Mokrišová, M. \& Suhányiová, A. (2014). Applying correlation matrix to identify the main factors influencing enterprise performance and their utilization to create creditworthy model. Journal of applied economic sciences, 9(3), 359-372.

Huai, Y., Lee, R., Zhang, S., Xia, C. H. \& Zhang, X. (2011). DOT: A Matrix Model for Analyzing, Optimizing and Deploying: Proceedings of the 2nd ACM Symposium on Cloud Computing, USA: New York, https://doi.org/10.1145/2038916.2038920

Hyránek, E., Grell, M., \& Nagy, L. (2014). Nové trendy merania výkonnosti podniku pre potreby finančných rozhodnutí. Bratislava: Ekonóm.

Kaplan, R. S., \& Norton, D. P. (2000). Balanced Scorecard: Strategický systém měřní výkonnosti podniku. Transl. by Šusta, M. Praha: MANAGEMENT PRESS. NT Publishing.

Kislingerová, E. et al. (2011). Nová ekonomika. Nové príležitosti? Praha: C. H. Beck.

Klieštik, T. (2009). Kvantifikácia efektivity činností dopravných podnikov pomocou Data Envelopment Analysis. Ekonomie a management, 12(1), 122-145. Retrieved from http://www.ekonomie-management.cz/download/1331826 707_1add/13_kliestik.pdf

Mařík, M., \& Maříková, P. (2005). Moderni metody hodnoceni výkonnosti a oceňování podniku: ekonomická přidaná hodnota, tržni přidaná hodnota, CF ROI. Praha: Ekopress.

Peters, T. J., \& Waterman, R.H. (1982). Search of Excellence. New York: Harper and Row.

Pollak, H. (2004). Jak obnovit životaschopnost upadajicich podnikú. Praha: C.H.Beck.

Rockart, J. F. (1981). "A Primer on Critical Success Factors" published in The Rise of Managerial Computing: The Best of the Center for Information Systems Research, edited with Christine V. Bullen. (Homewood, IL: Dow Jones-Irwin), OR, McGraw-Hill School Education Group (1986).

Sink, D. S., \& Tuttle, T. C. (1989). Planning and Measurement in Your Organisation of the Future. Ch. 5. Industrial Engineering and Management Press. Norcross. GA.

Štefko, R., \& Gallo, P. (2015). Using Management Tools to Manage Network Organizations and Network Models: Sroka, W., \& Hittmár, Š. Management of Network Organizations Theoretical Problems and the Dilemmas in Practice: 249-264. Springer International Publishing Switzerland, https://doi.org/10.1007/978-3-319-17347-4_17

Stern, J. M. (2015). Economic Value Added. Retrieved January, 20, 2016, from https://www.eva.com/

Suhányi, L., \& Suhányiová, A. (2014) Multi-criteria decision-making tool design for the investment decision-making of territorial self-government regions. Journal of applied economic sciences, 9 (1), 110-122.

Suhányiová, A., \& Suhányi, L. (2011). Application of international financial reporting standards (IRFS) in the Slovak republic. Lucrari stiintifice, seria I, 13(3), 267-274. 